\title{
Evolution and Conservative Christianity
}

\author{
How Philosophy of Science Pedagogy Can Begin the Conversation
}

\author{
Christine James ${ }^{*}$
}

I teach Philosophy of Science at a four-year state university located in the southeastern United States with a strong college of education. This means that the Philosophy of Science class I teach attracts large numbers of students who will later become science teachers in Georgia junior high and high schools-the same schools that recently began including evolution "warning" stickers in science textbooks. I am also a faculty member in a department combining Religious Studies and Philosophy. This means Philosophy of Science is often expected to provide dialogue, debate, and bridge-building on the issues of creationism and evolution. I am expected to provide a welcoming atmosphere to all the religious perspectives that the students bring to class, but at the same time I feel responsible for giving them a serious respect for evolution. This tension between religious tolerance and secular science education has had important consequences in American schools, most notably with the issue of Intelligent Design Theory (ID) in the classroom.

This paper begins with an analysis of the international differences in science pedagogy to contextualize the controversial issue of teaching evolution, creationism and ID. A number of international studies have critiqued teaching styles in science and math in United States schools, and some schools have successfully changed their science pedagogy to include more critical reasoning and abstract problem solving. The second section develops this notion of "inquiry based education" as it might relate to evolution and ID, and how it can take us beyond merely "teaching the controversy." The particular case of Steven Fuller's involvement in the Dover, Pennsylvania court case Kitzmiller v. Dover Area School District is discussed as an example of how the philosophy of science community might reflect on the methodology of science. The third section contextualizes the Dover case by comparing it with previous court cases in which the scientific method was analyzed in public legal proceedings. One of the most intriguing aspects of these court cases is the way in which expert witnesses are used. I will argue that the value of expert witness testimony is as a descriptive

\footnotetext{
*Christine A. James received her PhD in Philosophy from the University of South Carolina in 2000, writing a dissertation on philosophy of science, objectivity, and sonar technology. She has published a variety of articles and book chapters in scholarly journals including the Journal for Philosophical Practice, The Journal for the Study of Religions and Ideologies, The International Journal of Sociology and Social Policy, Essays in Philosophy, The Southwest Philosophy Review, and The Journal of Consciousness Studies. She also has an article forthcoming in the journal Biosemiotics on disability and communication.
}

Spontaneous Generations 2:1 (2008). ISSN 1913-0465. University of Toronto 185 
analytical tool, rather than as a normative prescriptive force. The final section of the paper will provide examples of narratives from students and teachers on both sides of the debate, illustrating how I attempt to shape these conversations while maintaining standards of good science as well as religious tolerance.

\section{The Context: International Comparisons of Pedagogy}

First, we need to understand the context of the disputes over Intelligent Design in the classroom on a national and international level. More than $30 \%$ of all graduate students in science, engineering, and technology programs in the United States are foreign-born students who hold temporary visas. This figure has grown steadily since the 1990s, with a brief slowdown after 9/11. Applications from foreign students for graduate study in United States science and engineering programs continue to grow, even in the face of strict visa restrictions since 2001 (NSF 2005).

As recently as April 5, 2006, The Nation reported that "US students have little interest in science or engineering as a career... patents filed by US inventors have started to decline, whereas patents from Asia are steadily increasing..." (Froetschel 2006) Some theorists argue that the disproportionate numbers of United States science students involves a prevailing anti-intellectualism. Research in current international science and math education, however, indicates that the genesis of the problem might not be merely brute antiintellectualism. Instead, studies of international testing comparisons, like the TIMSS (Trends in International Mathematics and Science Study) and the Programme for International Student Assessment (PISA) show that the teaching methods of the United States may be lacking in engagement and attention to conceptual background, and that this lack of engagement corresponds to less interest in science and math at the post-secondary level. To the extent that science and mathematics education adheres to a pedagogy that is lecture-based, relying on rote memorization of broad sets of facts, there is a commensurate lack of United States students entering science and engineering fields. The conclusion of the most recent TIMSS and PISA studies included recommendation for added engagement, practical application of theory, and group work on specific problems and issues.

The problem has been in the news for a number of years, and the complete TIMSS studies have been replicated a number of times over the last three decades. In a 1997 article from the International Herald Tribune, then-U.S. Secretary of Education Richard Riley said the TIMSS shows "our problem is not merely the amount of time U.S. students or teachers spend on mathematics and science but what they do with the time they have." (Fiske 1997) The international differences noted in the piece included that US teachers assign more homework, and spend more class time going over homework, than teachers in Japan and Germany. American teachers routinely stress breadth rather than depth; concepts, the undergirding theory and methodology of science, were left out of the picture. The basis for this claim is a comparative 
study of videotapes of teachers in the US, Japan, and Germany coordinated by James Stigler, Professor of Psychology at the University of California at Los Angeles. ${ }^{1}$

Riley also noted the importance of parental and community involvement in education: "We expect less from our children and, to our dismay, they meet our expectations." The study also found that while American teachers often have more academic credentials, teachers in the high-performing countries are better prepared in pedagogical skills and spend more time working with colleagues and honing their lessons. In the U.S., deeper consideration of methodology and creativity were sacrificed in favor of rote activities and going over exercises; especially after the No Child Left Behind Act, teachers submitted to the pressure of "teaching to the test."

To be fair, the TIMSS methodology has been critiqued. For example, in a 2007 piece featured by the Urban Institute, a policy "think tank" that tracks issues of domestic equality in the United States, B. Lindsay Lowell and Hal Salzman argue that US students are, videotapes aside, performing just as well as the other students in the written portion of the TIMSS. They note that:

It is not meaningful to draw international comparisons for the TIMSS results for high school students (often referred to as the "12th grade" test). The test is administered to students identified in each nation to be in their final year of secondary education. This is problematic because that final year of secondary school varies widely across nations from three years up to almost eight years beyond eighth grade. In other words, students completing secondary education in many other nations often have received more years of education than U.S. students...Should we be surprised if students who have received more coursework perform better on the same test? Consider that a completed secondary education in many European nations is often thought to be equivalent to a freshman year in an American college; hence, the ability of Europeans to move toward a three-year bachelor's degree. The twelfth grade TIMSS may reflect differences in sequencing of courses rather than performance levels of students who have studied the same subject matter. (Lowell and Salzman 2007, 17)

So, the argument goes, students taking the test have been taught fewer skills by $12^{\text {th }}$ grade in the United States than comparable-age students in other countries, and this justifies their poor performance on the TIMSS testing portion. However, they do not discuss the video evidence. Reconciling their comment

\footnotetext{
${ }^{1}$ The results of the video portion of the TIMSS are available at http://nces.ed.gov/TIMSS/
} 
with the videotape portion of the TIMSS reports indicates that not only are students in other countries receiving more information by their final secondary school years, they apparently also learned more of the conceptual and methodological basis of science and math, and they were given more opportunities to feel personally engaged in science. The videos show that teachers in the United States are less likely to make class interesting and let students feel involved and invested in practical applications. It would be one issue if, as Lowell and Salzman suggest, the only difference is one year of schooling, but unfortunately there is also something lacking in the preceding years.

Lowell and Salzman do address the issue of pedagogical approaches when they attempt to explain the lack of US students seeking careers in science and engineering fields:

...studies identify the quality of college education, be it inadequate teaching resources or poor pedagogy, as an important factor leading to attrition among S\&E majors during their college career. Indeed, the literature on the retention of college-enrolled S\&E majors almost uniformly identifies the causal factors of attrition as the pedagogical shortfalls of S\&E classes rather than student performance. (Lowell and Salzman 2007, 34)

Apparently, even when students do major in science and engineering fields, poor pedagogy makes them decide not to stick with it for a career. Teachers at the elementary, middle grade, and high school levels have responded to the situation by changing their pedagogy, and including a variety of new thought experiments and interactions in their math and science classes. For example, an article from a 2000 edition of Education Week, "A Teaching Style That Adds Up," addresses the question from the point of view of math and science teachers in the US who took the TIMSS study to heart and changed their teaching methods in light of its findings:

The (TIMSS) researchers found the U.S. curriculum a "mile wide and an inch deep," often covering topics in many grades, but never encouraging students to acquire a deep understanding of the material. For William Jackson and his colleagues (at Paterson Public School No. 2, an urban district outside New York City), the most compelling findings from TIMSS were its results on teaching methods. U.S. teachers show students how to perform mathematical functions, but don't challenge them to learn the underlying concepts of mathematics, according to the study. Jackson, who has taught at School 2 for 16 years, has discovered a new way to impart knowledge. He and his fellow teachers have written mathematics curricula for the 7th and 8th grades that is a mix of New Jersey's academic standards and the Japanese curriculum. More important, they've changed the way they teach 
in an effort to help their mostly high-poverty, immigrant students understand the concepts of mathematics, not just how to operate formulas. (Education Week 2000, 2)

The teachers who have used the results of the TIMSS video study have been able to approach their subject matter differently, and a wide variety of students have benefited from the change. The article describes how students from economically disadvantaged and first generation immigrant backgrounds have been able to participate in the discussions, group work, and conceptual focus of the revised classes, whereas the previous methods of formulas and going over homework left them behind.

The typical U.S. lesson, according to James W. Stigler and James Hiebert, the principal researchers on the project, consists of the following script: The teacher asks a quick question that requires a short answer. Then the teacher checks homework, distributes a worksheet, and monitors how students handle the questions. If students get stuck on a problem, the teacher explains how to solve it. At the end of the period, the teacher offers a quick lesson review.

The videotapes reveal a dramatically different approach in Japan. The teacher begins by reviewing what students learned the day before, and then the teacher assigns a problem for students to solve using that method. Ten minutes into the class, the heart of the lesson starts. The teacher assigns the problem for the day and tells students to begin solving it. Unlike problem-solving in the U.S. classes, where students are expected to employ a technique the teacher has explained, the Japanese problems are designed to prove a mathematical principle. Often, the problems will challenge the students to prove an underlying concept. Soon, the teacher invites students to work with groups. While students work, the teacher observes and responds when asked for help. Instead of showing the class how to solve the problem, the Japanese teacher coaches students by asking them questions that may help lead to a solution. By the end of the period, students have put their work on the blackboard and are invited to explain their findings to their classmates, according to The Teaching Gap: Best Ideas From the World's Teachers for Improving Education in the Classroom, the book that Stigler and Hiebert wrote explaining their research. (Education Week 2000, 2)

Since Lowell and Salzman did not discuss the videotape portions of the TIMSS study, their critique evaded some of the most important conclusions of the TIMSS results. Teaching science and math, and giving students an appreciation of 
science, is not only the result of test scores and rote memorization. The pedagogical techniques employed in the classroom have a dramatic effect on whether or not students feel engaged and connected with the material. Even at a young age, students are able to discuss concepts and principles that support math and science, and giving problem sets without the conceptual knowledge leaves students disengaged.

Although the "traditional" pedagogical approach has been criticized and teachers like those at Paterson have changed their methods, members of national science organizations have been careful not to blame the teachers as individuals. Their approach in the classroom, it is argued, merely reflects their own experience as students in math and science. In a 1997 speech before the National Academy of Sciences, Bruce Alberts, then President, noted that:

...there is a deeper lesson from the TIMSS results, one that is directly applicable to the professional lives of many Academy members. It is too easy to blame the teachers for the poor state of science and mathematics education. It is no wonder that so few of our precollege teachers teach science as inquiry. Almost none of them have ever experienced inquiry-based teaching themselves! We must accept a healthy portion of the responsibility for this state of affairs. Those of us who work at universities set the standards by which college science and mathematics are taught. We have given little thought to the fact that science teaching is almost entirely done by lecturing: After all, we were the " $A$ " students who learned well in this way. But research findings tell us that most students require an active involvement in developing ideas, in order to gain any understanding of permanent value. My field of biology provides a great example of how we fail to capture and hold student interest in science. As our knowledge of biology has exploded, the size of the textbooks used for introductory biology classes has grown accordingly. Biology 1 is generally believed to be a course in which all of biology must be covered in a single year and, under great pressure, biology classrooms therefore march through all of genetics, cell biology, ecology, evolution, and so on - a task that becomes ever more daunting with each passing year of scientific discovery. There are more new vocabulary words to be learned than there are in a first-year course in a foreign language. The superficial coverage of all topics makes it impossible to teach any of them for any real understanding...Most adult scientists, for example, spend relatively little time copying facts and definitions out of books, yet that is the primary activity of many students in science classes. For many children, exposure to science textbooks and to the culture 
of science classrooms results not in understanding, but in alienation from science. (Alberts 1997) ${ }^{2}$

How can teachers, school boards, and educational professionals in general fight this alienation from science? As a professor teaching philosophy of science courses that are taken by future science teachers, I hope to give my students meaningful and current ways to engage in conceptual and methodological discussions about science. The current controversy regarding Intelligent Design provides an excellent opportunity for philosophers of science to encourage students to think critically about science while respecting scientific method. The next section of this paper discusses the current controversy over teaching ID in science classes, and addresses how that controversy has been taken up in the science studies literature. Of particular interest is the Kitzmiller v. Dover Area School District case, in which members of the philosophy and sociology of science communities were called as expert witnesses. Cases such as this can be used as critical reasoning thought experiments among science students, and can give students the background needed to critique science and ID.

\section{Inquiry Based Science Education and ID}

The attention the National Academy of Sciences has given to the issue of inquiry-based and concepts-based education needs to be brought together with the recent controversy surrounding intelligent design and evolution. We should begin by acknowledging that citizens and students are both attempting some discussion of scientific method, in a limited way, when they debate the issue of science curricula in their local schools. School boards across the United States are dealing with challenges from the courts, from their state legislatures, or from their own high school students, asking them to include intelligent design or special creation in their biology classes. ${ }^{3}$

2 During Alberts' speech, he quoted "an astute observer of today's classrooms, professor of education Charles Anderson: "Science as represented in most textbooks seems to be pretty dull and disconnected stuff, certainly not something that most children would want to find out about in their spare time. Even more troubling, the culture of most classrooms where those textbooks are used has little in common with the culture of adult science. Most adult scientists, for example, spend relatively little time copying facts and definitions out of books, yet that is the primary activity of many students in science classes. For many children, exposure to science textbooks and to the culture of science classrooms results not in understanding, but in alienation from science." Anderson's work originally appeared in Policy Implications of Research on Science Teaching and Teachers' Knowledge, http://ncrtl.msu.edu/http/cseries/cs891v1.pdf

3 The concepts creationism, special creation, creation science and intelligent design all have particular meanings for various groups. It is somewhat beyond the scope of the paper to delve into that history, but here are some general guidelines. Creationism is usually the concept associated with earlier movements based on the book Of People and Pandas, which was published in 1989. It was the first text to use the phrase intelligent design, but in the years since it was published a variety of books have been written that develop intelligent design into 
One response is simply to "teach the controversy" and let a thousand flowers bloom-a view that has been satirized in a variety of media, including the comic strip Doonesbury. Teaching the controversy usually involves some combination of discussion on either side of the debate, and an expressed appreciation of the freedom to disagree-the conclusion is a murky relativism at worst and a naïve pluralism at best.

Teaching the controversy often leaves students confused, and can even contribute to the aforementioned unease many students feel about science and technology. Given the considerable methodological and conceptual questions raised by the ID issue, it is unfortunate but not surprising that many teachers seem unsure of how to approach it, and that the method of "teaching the controversy" is often adopted by default. Ironically, however, even the purportedly conciliatory approach of "teaching the controversy" has itself been controversial. The most recent example of a dispute over "teaching the controversy" came to a head with the case of Kitzmiller v. Dover Area School District, which hinged on the question of whether teaching ID as a viable theory alongside evolution represented a violation of the separation of Church and State. The case is interesting and important for the present discussion because Steven Fuller, a social epistemologist, testified as a rebuttal witness for the defendants. In December 2006 Social Studies of Science (SSS) published a special volume devoted in large part to a discussion of the Kitzmiller v. Dover Area School District case. In that issue of SSS, Kevin Lambert notes that "teaching the controversy" has been adopted as a strategy in the ID community, a strategy that specifically invokes the work of Thomas Kuhn, and which may have motivated the use of Steven Fuller as a rebuttal witness:

Offering ID and Darwinism as two incommensurable alternative theories is a strategy that emerged from arguments promoting the teaching of 'creation science' in high schools in the 1970s. By the 1980s, historian of science Thomas Kuhn was being invoked by creationists and supporters of ID to provide arguments that shored up the ID strategy of 'teaching the controversy'. Understanding how proponents of ID came to use Kuhn in order to promote equal classroom time for creation science and later ID will help show why the Thomas More Law Center wanted Fuller as a rebuttal witness, and the surprising degree to which Fuller's promotion of his own discipline, social epistemology, and the arguments for ID coincide. (Lambert 2006, 836)

a more complex pseudo or proto scientific theory. These more recent texts include Phillip Johnson's book Darwin on Trial and subsequent books by Behe (Darwin's Black Box, 1996) and Dembski (The Design Inference, 1998). Most people reference these more recent texts when arguing in favor of intelligent design, although as mentioned later in this paper, Of People and Pandas played a role in the recent Dover case. 
Lambert goes on to explain his understanding of Fuller's position, describing how the conflict between naturalism and religion in science education led to what Fuller calls an exclusion of the older tradition of natural theology from the current Biology curriculum. In essence, Lambert claims that Fuller argues for broader consideration of ID as a way to improve science, and to disabuse scientists of the assumption that natural theology did not contribute to the history of their field. Arguably, this is a misunderstanding of Kuhn's and Fuller's individual views, as well as Fuller's work on Kuhn. Thomas Woodward's first book on the ID controversy, published in 2003, describes the issue differently. A central idea of Kuhn's work is that there will be one scientific paradigm that dominates periods of "normal science," one conceptual apparatus that will be the standard for educating young scientists and that will serve as the basis for problem sets in textbooks as well as problems for working scientists to solve. Fuller argues against this idea. In looking back at the history of science it may be tempting to assume one monolithic paradigm was always organizing the work of the science community, but Fuller argues that science is in reality not so monolithic. Portraying the history of science as guided by a single paradigm, even for specific periods of "normal science," is at best a "rational reconstruction," an artifice to make scientists' decisions appear to conform, and at worst a symptom of "'Orwellian' whig history." ${ }^{4}$ Often, expert witnesses are chosen specifically because of their divergent opinions on the history and methodology of science.

If one hopes to address the controversy with the assistance of "expert witness testimony," one must delineate which expert opinions actually count and why. A variety of separate issues intersect here: Should the "expert witnesses" be scientists or those who, as in science studies and social epistemology, study the scientists? Should they be invested in one side of the debate, or should they have a keen understanding of the debate, its history, its context, and the merits of each side? Should the testimony of these witnesses be limited to issues on which the field unanimously agrees? A number of articles in

${ }^{4}$ The notion of "whig history" is a paraphrase of comments by Steve Fuller in Kuhn vs. Popper (especially page 54), in which he describes and critiques the histories of science that assume a heroic, linear progression toward the truth: "Unfortunately, this peculiar feature of the philosophy of science is lost amid blanket postmodernist attacks on 'master narratives', including ones where mastery occurs in the afterlife or the indefinitely deferred future. Master narratives are historical accounts of history that presuppose an active universal subject-one with whom the author happens to identify-who overcomes a series of obstacles to reach full self-realisation. That plot outline is common to the invisible hand of Divine Providence in the Christian salvation story, the philosophical histories of progress recounted in the Enlightenment, the path of the world-historic spirit charted by Hegel, and the scientific theories of dialectical materialism and evolutionary naturalism inspired by Marx and Darwin. The style in which these histories are typically written is often called Whig history, named after the victors of the $17^{\text {th }}$-century English Civil War, who wrote of the conflict as one they were bound to win as defenders of liberty. (Fuller 2004, 54) 
the Social Studies of Science issue dealt with these questions, especially those by Lambert, Gorman, and Cole, who share their experiences as expert witnesses. Most practicing scientists are surely willing to discuss the questions raised by ID. Lambert argues that no one on the evolution side of the debate would claim that "the difficult technical and theoretical issues raised by scientists sympathetic to ID, such as Michael Behe or William Dembski, should not be debated by research scientists in their particular field of expertise." (Lambert 2006, 840) Those on the evolution side of the debate are open to the conversation. The conversation becomes problematic when one tries to show that those sympathetic to ID and those researchers engaged in ID's questions have "done enough to warrant a place in a high school science curriculum," (Edmond and Mercer 2006, 847) which should generally avoid speculative or tentative hypotheses and focus on the best and most secure knowledge available. Fuller's expert testimony was often used as a way to critique the ID community, as Gary Edmond and David Mercer put it, as a "foil." Fuller's concessions on the stand, noting the ID community's lack of peer reviewed publications and testing, were used by Judge Jones as a way to support the link between ID and religion, and as a way to demarcate science from religion. (Edmond and Mercer 2006, 848)

The most effective response to the controversy, among members of the science and philosophy of science community who are interested in pedagogy, would strive to find narratives that will be meaningful for multiple purposes. We must connect with conversation partners in ways that respect and show tolerance for a variety of religious beliefs, and at the same time, try to alleviate some of the overwhelming fear and mistrust of science. Narratives, when discussed directly and with the application of critical reasoning skills, can have pedagogical value. If philosophers and scientists are not dealing with the issue directly, then we have to acknowledge that creationists, creation scientists, and intelligent design advocates have always been straightforward about their desires to have ID taught in the classroom. At the same time, any expert from the STS or SSK community would have to remember not to "go native" and adopt the views of the group recruiting their expert testimony on issues of science and pseudo-science. (Gorman 2006, 863) This is especially true for any expert witness coming from the position of Fuller's social epistemology, since "the multidisciplinary origins and variety of hermeneutic approaches underlying STS and SSK perspectives may deter the promotion of simple, prescriptive, or consensual answers to questions about method, demarcation, and reliability." (Edmond and Mercer 2006, 849) 


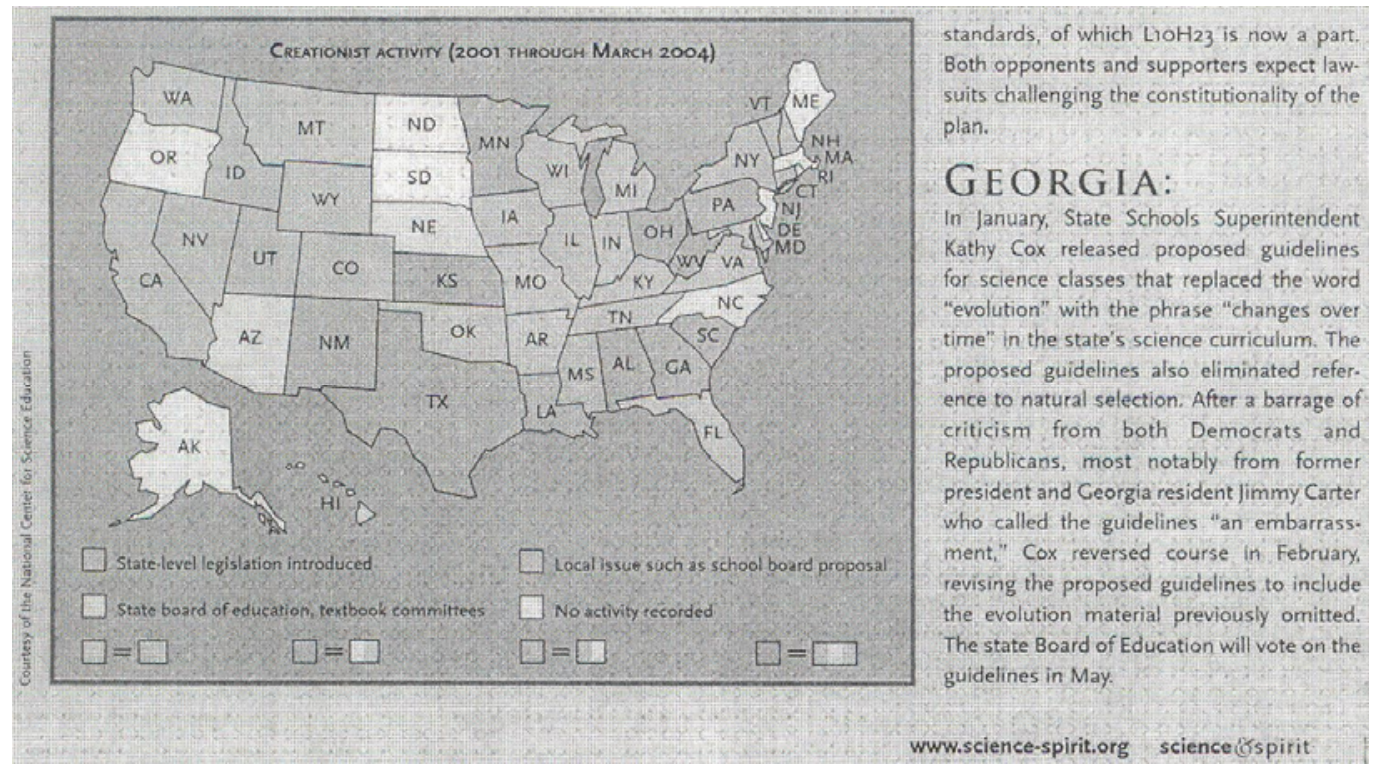

Figure 1: Political activity affecting ID in schools by state. (Science and Spirit 2004)

Most states in the United States have had some activity with regard to evolution and intelligent design. Figure 1, a map from the journal Science and Spirit, shows a heightened level of intelligent design debate in many school districts in 2004, before the recent cases in Kansas and Dover, Pennsylvania were underway.

Is this recent activity connected to the work of ministries, such as Ken Ham's Answers in Genesis? His presentations at churches have excellent attendance, and he and his musician colleague "Buddy" have spread their message in many states over the last ten years. My students who go on to become science teachers are often familiar with Ken and Buddy from their childhood, and I expect their future students will be as well. The Science Studies community has also become familiar with Ken Ham's work. Simon Cole, in the same December 2006 issue of Social Studies of Science, mentions how much Ken Ham's methodology reminds him of Bruno Latour's critique of science:

...it must be admitted that Ken Ham's instructions for 5-year-olds to question the authority of teachers who presume to lecture on the Big Bang-'Excuse me, were you there?'-sound disturbingly reminiscent of Latour's (1987: 76) impish questioning of 'the Professor'...in other words, ID seems like one of those cases of 'science studies gone awry' that have always lurked beneath the surface of science studies' critical project. (Cole 2006, 855)

The key question is how to encourage students to question in productive ways, both questioning ID and questioning science. Students should never be discouraged from asking questions, but neither should the types of ideologyladen and leading questions asked by Ken Ham be held up as exemplars. The 
challenge, which is only greatened by the aforementioned lack of discussion of methods and concepts of science in classrooms, is to encourage students to ask the kinds of questions that lead to constructive dialogue and greater understanding.

The lack, or alternately incoherence, of critical discussions of science in the classroom is tied to both trends in the expression of religious beliefs and the way we teach science. A Gallup poll report from March of 2006 claimed that more than half of all Americans do not believe in evolution and take a literal interpretation of the book of Genesis. The poll asked that participants choose one of three statements as most representative of their beliefs. Around 53\% said that they believe that God created man, exactly as the Bible described it; $31 \%$ believe that man did evolve but God guided it; and 13\% believe God had no part. (Editor and Publisher, March 8, 2006) If this Gallup poll is correct, and one should note that it is widely disputed, it is understandable that some portion of the population wants to include their religious beliefs in the science classes of their children. One of Steve Fuller's major arguments given in support of ID rests on the notion that in the history of science, religious perspectives and natural theology played a significant role in the advancement of science. In the next section, other court cases involving scientific method will be addressed with the goal of clarifying how the criteria of science and pseudo-science is relevant to the issue of natural theology raised by Steve Fuller.

\section{Legal Precedents}

The number of court cases involved has dramatically increased, and so citing the legal precedents is one important facet of teaching the controversy over ID. Marjorie George's article "And Then God Created Kansas?," from the University of Pennsylvania Law Review, analyzes a series of decisions from state courts as well as the Supreme Court. These decisions resulted in a specific set of criteria for revising science curricula.

One example is the Lemon Test, named for the 1971 Lemon vs. Kurtzman case, which came to the Supreme Court from Louisiana. Lemon established that any statute changing science curricula is unconstitutional, unless 1) the legislature adopted the law with a secular purpose, 2) the statute's principal or primary effect must be one that neither advances nor inhibits religion, and 3 ) the statute must not result in excessive government entanglement with religion. (George 2001, 847) These criteria were later refined and debated by two philosophers of science, Michael Ruse and Larry Laudan. In McLean v. Arkansas, Judge Overton upheld five standard characteristics of science that were recommended by Michael Ruse:

1. guided by natural law

2. explanations refer to natural law

3. testable against the empirical world

4. conclusions are tentative, not final word

5. falsifiable (Ruse 1982, 16-19) 
Overton said creation science does not meet all the necessary criteria for it to be considered science. In testimony, Ruse held that Creationism does not meet the criteria of testability, falsifiability, and revisability because there are no circumstances under which the creationists would give up any of their central doctrines. If the Bible is the word of God, any "evidence" in conflict with it must either be mistaken or a part of the "law" of man rather than the law of God. Creation science appeals to processes used by God that we cannot comprehend, and asks for membership documents that reflect the non-scientific nature of these beliefs. ${ }^{5}$ While Judge Overton borrowed his criteria for science from Michael Ruse, another philosopher of science, Larry Laudan, took these five criteria to task. Laudan argued that creation science is both testable and falsifiable; indeed, it has been tested and proven false. Other scientific theories were not initially guided by natural law or used explanations referring to natural law. Laudan says we cannot pretend that science has more "open-mindedness," and "natural law" is a "fuzzy" concept anyway. (Laudan 1982, 29) This particular quote of Laudan notes that the very concept of a scientific law itself can be critiqued for various reasons (including uncertainty, political motivations, and a variety of exceptions to accepted laws).

The most recent and highly publicized legal decision, Kitzmiller v. Dover Area School District, follows from these legal precedents. In Kitzmiller, Judge John E. Jones III asked whether the school board's actions on intelligent design were an endorsement of a religious belief on the origin of species, and whether the school board's purpose or intent was to promote specific religious beliefs. (Dowling-Sendor, 2006) Judge Jones' decision stated that intelligent design is a theological concept, rather than a scientific theory. Following Judge Overton's decision in McLean v. Arkansas, Jones stated that the scientific method "limits inquiry to testable, natural explanations about the natural world. It requires

5 One infamous example of such a document is used by the Creation Research Society: "there is nothing tentative or empirically checkable about the central claims of creation science. Creationists admit as much when they join the Creation Research Society (the leading organization of the movement). As a condition of membership applicants must sign a document specifying that they now believe and will continue to believe: (1) The Bible is the written word of God, and because we believe it to be inspired throughout, all of its assertions are historically and scientifically true in all of the original autographs. To the student of nature, this means that the account of origins in Genesis is a factual presentation of simple historical truths. (2) All basic types of living things, including man, were made by direct creative acts of God during Creation Week as described in Genesis. Whatever biological changes have occurred since Creation have accomplished only changes within the original created kinds. (3) The great Flood described in Genesis, commonly referred to as the Noachian Deluge, was an historical event, worldwide in its extent and effect. (4) Finally, we are an organization of Christian men of science, who accept Jesus Christ as our Lord and Savior. The account of special creation of Adam and Eve as one man and one woman and their subsequent fall into sin, is the basis for our belief in the necessity of a Savior for all mankind. Therefore, salvation can come only through accepting Jesus Christ as our Savior." (Young and Largent 2007, 249) 
scientists to seek explanations in the world around us, based on what we can observe, test, replicate and verify." In contrast, intelligent design "takes a natural phenomenon and, instead of accepting or seeking a natural explanation, argues that the explanation is supernatural." (Dowling-Sendor, 2006) Judge Jones also stated that "intelligent design assumes a false dichotomy, (claiming that if) evolutionary theory is discredited, intelligent design is confirmed." Here, Jones acknowledged a classic misunderstanding about the amount of testing a scientific theory goes through, as opposed to an everyday idea or hypothesis. Evolution has the status of a scientific theory because it has withstood strenuous testing and many of its hypotheses have been confirmed. Intelligent design, on the other hand, has actually seen its lynchpin concept of irreducible complexity disproven by testing. A system demonstrates irreducible complexity, it is claimed, if removing or altering any one component would destroy its functionality. This is supposed to disprove evolution through natural selection, since it is argued that no such system could possibly have arisen through gradual changes. Unfortunately for ID theorists, many purported examples of irreducible complexity, such as the complex system of proteins involved in blood clotting, have been shown to be consistent with natural evolutionary processes, weakening irreducible complexity's rhetorical effect as an argument against evolution. ${ }^{6}$ Jones also stated that the intelligent design argument based on inference of design from the "purposeful arrangement of parts" is an unverifiable theory and a warmed over version of historical arguments from design. A classic example is William Paley's 1802 watchmaker argument. (Chapman 2006, 58)

It was exactly this type of natural theology perspective that Fuller tried to bring to bear on the ID controversy in the Kitzmiller v. Dover case. In the December issue of Social Studies of Science, Fuller discussed how the initially important role of the supernatural (including hypothetical entities, be they God, phlogiston, or unobservable microorganisms like Latour's heroic yeast proving itself) in the history and advancement of science has a way of disappearing over time. As experimental proof is found that gives an alternative explanation, a kind of rational reconstruction occurs in which the context of justification (experiment, proof) is read back into the context of discovery (inspiration, divine or otherwise).

\footnotetext{
${ }^{6}$ For further discussion of the irreducible complexity issue, see the work of William Dembski. For example, the book No Free Lunch (2002), which has been reviewed in a variety of sources. Richard Wein reviewed the book on http://www.talkorigins.org/design/fags/nfl/

"Dembski repeats the claim that the problem of explaining the evolution of IC molecular systems has "proven utterly intractable" (p. 246), but evolutionary explanations have now been proposed for several of the systems cited by Behe, including the blood-clotting cascade, the immune system, the complement system and the bacterial flagellum. The last of these is highly speculative, but is sufficient to refute the claim of utter intractability."
} 
...the role of the supernatural in the advancement of science comes to be erased once experimental proof is found for these originally mysterious entities. The context of justification is effectively read back into the context of discovery, which then makes methodological naturalism look persuasive. Newton's and Mendel's theistic inspirations are relegated to superfluity, since subsequent experiments and attendant reasoning are sufficient to demonstrate gravity and genes. This makes methodological naturalism a natural concomitant of a Whig historiography of science, whereby the past is seen in retrospect (from where it ended up), not in prospect (from where it emerged). The interesting exception, as one might expect, is Neo-Darwinism itself, where 'natural selection' has figured in less than $1 \%$ of the abstracts of all biology papers indexed since 1960...these wranglings over the history and philosophy of science must return to the requirements of high school science education. Presumably one wishes to promote an interest in science within the confines of the law...(Fuller 2006, 829-830)

The question of faith in science studies has led to a range of results in the courts. In some cases, science studies testimony was not allowed. In the December 2006 issue of Social Studies of Science, Simon Cole discussed his experience as an expert witness in a trial where he was expected to criticize fingerprint analysis:

The government (prosecution) filed a writ to quash the judge's order allowing my testimony. On 20 January 2006, the $3^{\text {rd }}$ District Court of Appeal of Florida heard oral arguments in the case. In this argument, I later learned, one member of the three-judge panel argued that criticizing fingerprinting was akin to advocating creationism. In other words, even as Fuller committed possible science studies heresy by mustering his science studies credentials in defense of ID, in another courtroom across the country, creationism was invoked by way of analogy to highlight the heretical nature of a science studies expert's claims-claims which, it should be noted, are increasingly being supported by 'mainstream' scientific opinion (Siegel et al, 2006). The creationist analogy is all the more paradoxical in that it is precisely the faithbased nature of fingerprint examiner's knowledge claims that I propose to criticize, and it is precisely my contrasting of that 'leap of faith' (Stoney, 2002) with a perhaps idealized notion of scientific knowledge that invites questions about whether I speak 'on behalf of the field'. (Cole 2006, 859) 
Cole raises the issue of "speaking on behalf of the field" in a very specific normative, prescriptive sense. In the next section, I will address how disagreement in public debate, even disagreement between expert witnesses, can be helpful for students learning how to use critical reasoning to debate on the scientific method. This descriptive analysis of the history of science (rather than normative claims) has a purpose even in inquiry-based science courses, not merely in humanities, social studies, or comparative religion courses.

\section{The Creation of Public Science and the Value of Disagreement}

In the Kitzmiller case, the issue was not expertise or who speaks on behalf of the field of science. The nature of the beliefs behind ID, and the agenda regarding religious beliefs in school determined Judge Jones's decision. Above all, Jones concluded that intelligent design is a religious belief, based on statements of key school board members who admitted as much in their testimony. (Dowling-Sendor, 2006) A key player in the Dover case was Reverend Groves, who arranged for sixty copies of the ID text Of People and Pandas to be available to students in the Dover schools. Groves "was unashamed of a literal reading of Genesis and an earth that was only 6,000...years old. To him, carbon dating was nonsense, and that was that." (Chapman 2006, 58)

The amount of effort spent in the Social Studies of Science issue discussing who is a legitimate expert witness can help us to express exactly why Reverend Groves is not someone who provides an informed critique of science. $\mathrm{He}$ is neither a scientist, nor one of the sociologists or philosophers of science who study the debate, and furthermore he was not able to articulate a clear critique of carbon dating. But he stands as an example for students in science classes today. The goal should be to create an atmosphere of critical reasoning about science in science education, an atmosphere most unlike that described in the first section, in which the TIMSS exposed the lack of critical reasoning in science classrooms. Putting together the science education studies and the court cases provides a clear portrait of what is happening in the socio-judicial debates about science: many parties want to take part in the debate about what "good science" is, and many are ill-equipped to take part in that debate.

This issue was addressed by Edmund and Mercer in a variety of publications, including Social Studies of Science:

Following the tradition around the Scopes trial, McLean v. Arkansas Board of Education, and more recent 'creation science' litigation, Kitzmiller can be understood as an opportunity for interested parties to engage in the creation of public science (Gieryn et al. 1985; Edmond \& Mercer 1999; Mercer 2006; Edmund and Mercer 2006, 846)

Placing limitations on who can take part in the creation of public science, especially in a context where students are not well-versed in critical reasoning, seems to be the wisest approach. An infusion of philosophy of science debates in 
the science classroom would provide a way for students to understand these proclamations about science, and dissect where they are coming from and why. In Lynch's article in the Social Studies of Science issue, he notes the challenges that come from adding science and technology studies (and presumably the philosophy of science) into the public debate. One challenge comes from the distinction between the descriptive and the normative: if sociology of science unavoidably makes normative prescriptions about how science ought to be done, this normative engagement puts the sociologist or philosopher of science in a compromised position, where they either "go native" to the group they agree with, or they remain silent in an attempt to maintain unbiased perspectives on what "good science" should be:

The dilemmas arise from efforts to follow through on proposals to use science and technology studies as a basis for engaging in public controversies. I believe it is fair to say that there is a strong trend in S\&TS circles toward advocating some sort of normative engagement in techno-scientific politics. It has gotten to the point that anyone who expresses skepticism about that trend risks being consigned to quietism or, worse, mere academic professionalism. Nevertheless, I think it is worth pointing out that calls for engagement face a difficulty with reconciling symmetry and/or impartiality-often held to be principled cornerstones of a constructionist stance toward science-with the unqualified advocacy often demanded of participants in public controversies and tribunals...a possible way out of the dilemma is to suppose that an expert can intervene in hopes of restoring a modicum of symmetry in an asymmetric dispute between powerful claimants of scientific truth and opponents who are charged with holding pseudoscientific, magical or merely commonsense beliefs. (Lynch 2006, 820)

I agree with Lynch, that an expert can intervene in certain cases. The challenge, of course, is sorting out which types of experts can be the most helpful. The strength of philosophy and sociology of science in these debates lies not in their normative or prescriptive ability, but in their ability to perform descriptive analysis and uncover the genealogy of disagreements and challenges to the status-quo of science. A number of the expert witnesses called in such cases might intend to do this descriptive analysis, and might do it very well. Yet they have to avoid, as much as possible in the face of public perception and media misconstruals of their work, an appearance of making normative claims. The biggest problem we now have in the public debate about ID, and about other issues in which science and ethics appear to collide, is that people often do not have the background to understand the ethical implications of a scientific theory, or they assume ethical implications when in reality the scientific theory is 
merely attempting to explain why things "are" the way they are, not how things "ought" to be. Descriptive explanation has a very important role to play in expert testimony. Normative claims, or the lack of such normative claims, must be held as significant as well (as in the case of Fuller's testimony at the Dover trial, in which he explicitly refused to give a positive statement in favor of $O f$ Pandas and People). We have to acknowledge that the average person might jump to a normative conclusion with some expert testimony, and there is a compelling imperative for any expert witness to state clearly and often whether he or she means to explain a situation, or rather to give normative prescriptions. Where scientists themselves are ill-equipped to address this normative-descriptive distinction, philosophers and sociologists of science are well-versed already. This is why someone like Steve Fuller can be completely consistent when he notes the importance of natural theology in the history of science, and simultaneously hold that no specific religious doctrine is implicated in this view. A careful understanding of science, in the descriptive sense, allows for an understanding of what can contribute to science without making it the handmaiden of a specific religious point of view.

This point about descriptive work, as opposed to normative work, dovetails with another issue raised by Cole in his discussion of expert testimony. Cole asks whether expert witnesses must restrict their testimony only to arguments that are already unanimously decided by "the field" in general. If one of the central arguments here is that critical reasoning in science education is good, and that such critical reasoning requires a background in and an ability to evaluate the descriptive task of philosophy and sociology of science, then it should also follow that disagreement, and the careful analysis of disagreement, is also an important good in science education. As Cole notes, limiting expert testimony (or the analysis of sociologists and philosophers of science) to issues of unanimity would be limiting to the point of absurdity:

Why should we expect science studies practitioners who serve as expert witnesses to restrict themselves only to arguments that would command unanimous assent from 'the field' when we who study other experts would not expect it of them? Is it because, despite our differences, we are still closer to being a movement than a discipline? Is it because relativism and reflexivity prompt us to think about such questions to an extent that positivists do not? Obviously, a requirement of unanimity would restrict us to rather banal arguments, especially in a field as diverse as science studies. The notion becomes doubly absurd when applied to Fuller, who has expended much effort articulating differences between himself and 'orthodox' science studies. (Cole 2006, 856)

The issue of relativism, or the appearance of relativism in some science studies circles, might cause some to argue that science classes are not the place to have the critical reasoning debate about science. For example, the American School Board Journal published a two part series on the Kitzmiller case in March 
of 2006, and endorsed the view that there simply is no justification for teaching intelligent design in the science classroom, but that other contexts (such as classes in humanities, social science, world religions) would be a possible venue to address and teach intelligent design as well as other religions and beliefs. This same view was expressed two years earlier, in the journal Science and Spirit, with a quote from Skip Evans of the National Center for Science Education: "We would be more than comfortable to see creationist and ID views in a comparative religion class or in a humanities class, but not in a science class." (Martin 2004, 12) I would not argue against including some discussion of the historical aspects of ID in comparative religion and humanities courses, but I do worry about the specific practices involved. Some states in the U.S. have added "Bible as Literature" classes to their humanities offerings. A study of the curriculum recommended for this courses shows that the thrust of the work in such classes is not a critical reasoning approach to the Bible, or an historical analysis of the Bible as a text; rather, it is a way to increase Christian content in high schools. I would be concerned that high schools are either unable to offer a true comparative religion class without overemphasizing Christianity, or that when such classes are offered they are not providing accurate information with regard to the ID controversy. Philosophers of science, who have an understanding of descriptive analysis of the history of science and who have skills in critical reasoning and logic, are better suited to the needs of students beginning to analyze science. The best place to do this analysis would be the enriched science education classroom described in the TIMSS and other studies. In the final section, I will provide example narratives from students and teachers discussing science and discussing their beliefs. These sample narratives are the type of critical reasoning discussion that deserve a renewed place in the science classroom, combining inquiry and analysis of the scientific method with a means of making science more interesting and more accessible to students.

\section{Teaching Practices as Critical Reasoning Practices}

Philosophers of science can play a unique role in the training of future science teachers, because the philosophy of science is able to produce both narratives on issues of disagreement among scientists, and the critical reasoning skills that can make such narratives instructive. We have our mainstream philosophers of science, who hold up criteria like the Lemon test and Michael Ruse's five criteria as a gold standard. We also have our share of more radical theorists, who believe that the history of science has assumed too much and too often that science is objective, universal, or privileged, and who hold that what counts as science must be broadened. The counter-traditions, it is argued, deserve a voice, giving science a "free market of ideas" quality. Steve Fuller made arguments like these regarding ID in his capacity as an expert witness in 
the Kitzmiller case, and he has responded to his critics in a variety of forums since the trial.

In one source, Fuller notes: "Someone here mentioned some affinity between my view and Feyerabend's "anything goes." Actually I don't believe "anything goes," I'm making a specific case about ID. ID deserves space less for what it's done recently, than as a representative of the main counter-tradition in the history of science to the one represented nowadays...one cannot understand the heuristic value of this belief in the history of science... the fact that contemporary ID is not well-supported matters much less to me than its potential for inspiring new directions in the scientific imagination." (Fuller 2006a) Fuller's view is part of a tradition in critique of the social and historical locatedness of science, and has connections to Larry Laudan's comments on the previous Arkansas case. Laudan argues that the victory in the Arkansas case was pyrrhic: it was achieved at the expense of perpetuating and canonizing a false stereotype of what science is and how it works. Pro-science forces are defending an outmoded philosophy of science. (Laudan 1982, 29c1-2) Fuller's point is well taken, but to some extent he has actually fed into the fear of science that I am aware of when I talk with my students. When experts like Steve Fuller argue that science is doubtful, or that it is in any way less certain than it promises, some students take it as a carte blanche to dismiss all science, and not pursue careers in engineering and technology. This claim, that students are not pursuing careers in science and technology in the United States, is supported by a variety of anecdotal data, and is consistent with the earlier review of the TIMSS studies. It is not clear to me that either the lack of problem solving and critical reasoning skills in US science classes found by the TIMSS results, or the sociologists' "doubtful" critique of science taken alone are individually sufficient to convince students not to engage in science careers. However, there is significant anecdotal evidence linking both of these factors to the declining numbers of US students engaging in science and technology careers.

One piece of anecdotal evidence comes from the October 2005 issue of Software Development magazine, and a number of letters to the editor and blogs that responded to it. The issue asked whether postmodernist doubts had ruined science and technology education, and in turn, the field of software development. A number of respondents agreed, claiming that postmodern doubts about science had caused some bright students to choose careers outside of software development. As one comment noted, earlier generations had entered technology because politics and law appeared to be the new sophistry: "Like many Russians under Brezhnev, my generation (born in the 1940s and 1960s) entered technology because Nixon, like Brezhnev, made us cynical about politics and law...it seemed to be a massive grab-ass." ${ }^{7}$ The same problem seems to happen a generation later in science and technology. The

${ }^{7} \mathrm{http}: / /$ www.developerdotstar.com/community/node/261 is one such discussion of the October 2005 issue of Software Development; entitled "Has Postmodernism Ruined Science and Software Development?" by Daniel Read. 
point is not to question whether Nixon, Brezhnev, or the whig history of science should be criticized-they should-but to enhance student experiences with a supply of critical reasoning skills so that they can find their way out of the cynicism that makes them want to leave the field in the first place. A notable exception is the currently growing field of biomedical sciences. The growth in health-related fields is probably related to the way in which biomedical sciences have been able to assimilate postmodern insights from communicative ethics into their interpersonal practices over the last forty years, and the new contextual narratives of patient choice and increased health product advertising, which increases the profits of the pharmaceutical industries and other health related fields.

Also note that Steve Fuller has actually said he defends the Michael Ruse criteria-in a March 2006 piece in the Science and Theology News, Fuller states that it was unfortunate that Judge Jones based even part of his decision on the religious motivations or intentions of the members of the school board. (Fuller 2006b) In an interview with The Guardian, Fuller notes the significance of Michael Ruse's testimony: it was the first time that a philosopher of science had taken the stand in the evolution controversy, and it illustrated how philosophy of science could be valuable in establishing the methods, the first principles, and the reflection necessary for science to improve.

As you can imagine, the dominant narratives about Christianity, nature, and science in this context involve conflation of stewardship and dominion over nature. In theoretical work in Religion and Nature, Mark Wallace discusses the growth in pantheism and Christianity's mutual connection and reclaiming of one another, expressing a spiritual and scientific appreciation for nature through narratives. $^{8}$ I do believe that there are such narratives that can assist in broadening the approach of a philosopher of science who deals with the evolution issue, and which can be used in the enriched science education setting described earlier.

Including these narratives can be a bit of a challenge. In the southeastern United States the available narratives tend to invoke religious beliefs in a strong sense. In 2004, various counties in Georgia began passing legislation to include warning stickers about evolution in textbooks. These stickers have since been declared unconstitutional, and have been satirized to great effect. ${ }^{9}$

\footnotetext{
8 Mark Wallace presented work on religion and nature during a session on "The Emergence of Religion and Ecology as an Academic Field" at the conference "Exploring Religion, Nature and Culture, The Inaugural Conference of The International Society for the Study of Religion, Nature \& Culture" on April 6-9th 2006 at the University of Florida in Gainesville, Florida. The author of this paper was also a participant/presenter at that conference.

9 A related issue recently faced in the Georgia legislature involved sales tax exemptions on purchases of religious texts. Until a couple of years ago, one could purchase a Bible in Georgia and not pay sales tax. The exemption was never extended to other religious texts, and was finally struck down only recently.
} 
This textbook contains material on evolution. Evolution is a theory, not a fact, regarding the origin of living things. This material should be approached with an open mind, studied carefully, and critically considered.

\section{Approved by \\ Cobb County Board of Education \\ Thursday, March 28, 2002}

Figure 2: A sticker put on biology textbooks in Cobb County.

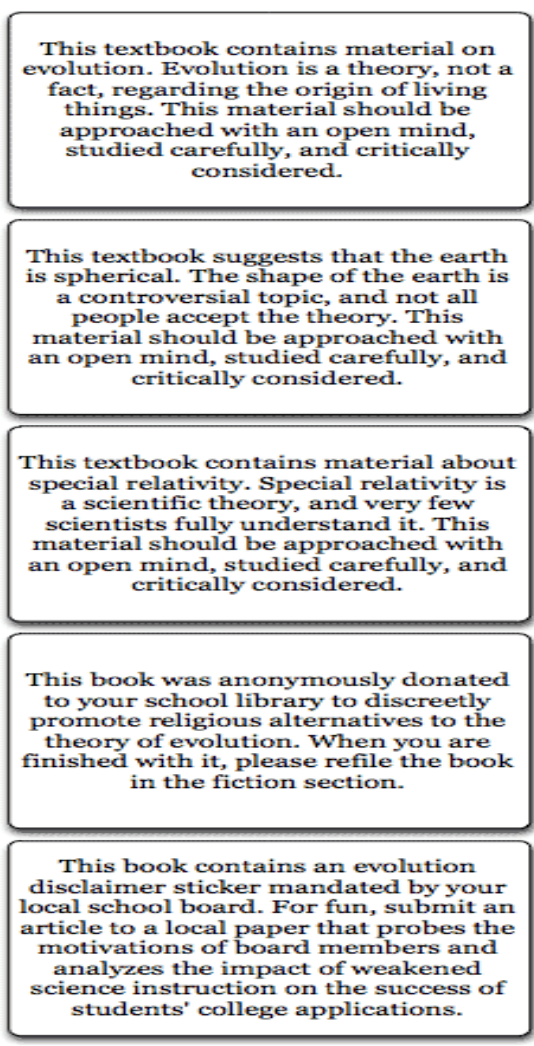

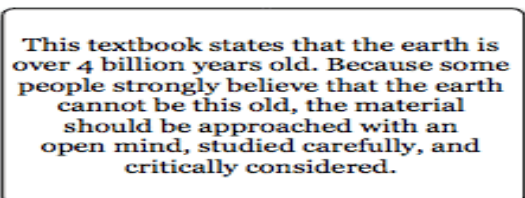

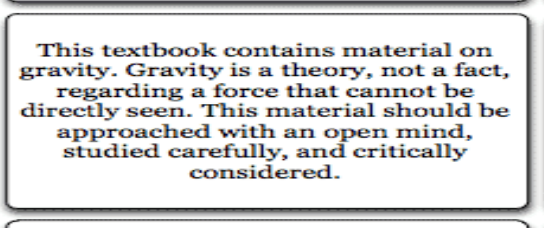

This textbook claims that evolution is not fully accepted by scientists

because it is just a theory. The author hopes to confuse you into equating "scientific theory" with "cockamam what a scientific theory is, go to: http://wilstar.com/theories.htm

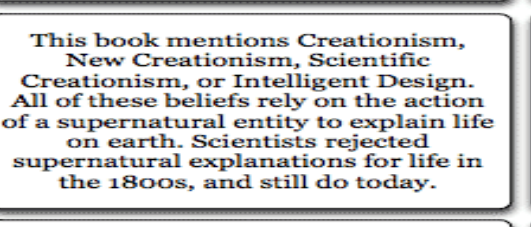

This sticker covers a pre-existing sticker designed to subtly undermine the teaching of evolution in your
class. To see the full text of the original sticker, examine the books of children of school board members, who mandated the stickering.

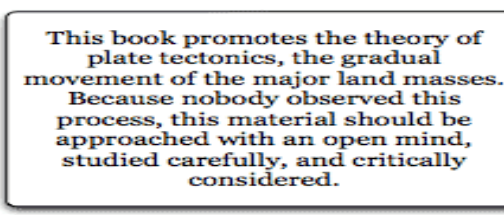

This book discusses heliocentrism, that the Earth orbits around a centrally located Sun. Because astronomers still disagree over the details of the heliocentric model, this material should be approached with critically considered.

This book does not contain the word evolution, the unifying principle in

of and the Scholastic Achievement Test. For an overview of what your class is missing, go to:

http://evolution.berkeley.edu/

This book discusses gods. The existence of entities with supernatural powers is controversial, and many believe that myths, especially other people's myths, are fctional. This material should be studied carefully, and critically considered.

This book discusses evolution. President George W. Bush said, "On the issue of evolution, the verdict is still out on how God created the material shood be aproched with an material shood be aproched with an critcly consid"rd.

Figure 3: Satirical responses to the Cobb County sticker.

As a philosopher of science, I consider myself responsible for remaining conversant with these issues. I think that one of the best pedagogical moves we can make is to help students understand not only science, but also philosophy of science. The current science curriculum focuses on specific lessons and labs, the received view of science, and the classic problems embodied in standard texts; to whit, what Thomas Kuhn called "normal science." There was a time when I hoped that science education was not really so staid, based on a model of student as passive receiver of knowledge through lecture, with little discussion or dialogue. Unfortunately, I have to say it is challenging to find evidence to the contrary. For example, I often do guest lectures in Biology, Chemistry and 
Psychology classes discussing ethics and the scientific method. One class in particular is a senior level seminar for Chemistry students. After thinking a great deal about how to connect with their lived experience, I put together a variety of case studies involving chemists in ethical debate. I gave them background information in ethical theory and then asked them to discuss their cases in groups. The students were interested and engaged, but I could tell that the discussion model was new to them-a few asked what to take notes on. Their Chemistry faculty member loved the case studies and joined in with the students as they worked out their examples-after the class he told me he was surprised that they spoke up as much as they did, since the senior seminar, along with most of the other courses in the Chemistry curriculum, was based on lectures, note taking, and lab work. "They don't usually talk," the professor said. After learning their science, there was too little time left to critically engage with why they do things the way that they do. The notion of scientific method, even in the sense of Ruse's five criteria, was not familiar to these students as such. These are the students who will potentially be called on later in their careers to defend their curriculum before school boards and courts of law, but we are not preparing them with the critical tools they will need to provide a reasoned definition of what good science is. The result is that we have a disconnect not only in terms of justifying relationships between religious beliefs and the law, but also in terms of how scientists are able to describe what they do.

I think this may be a part of the problem with the current evolutionintelligent design controversies. It is not only an issue of religious motivations on the one side, but also an issue of how we teach science, or rather how we do not teach methods, principles, and critical reasoning alongside science. Even though any science teacher is probably willing to discuss such issues with students, and I am sure that my dear colleague in Chemistry was, there are so many pressures that prevent substantive treatment and reflection on these issues in the average science class. The class size, the time it takes to set up labs, the inadequacy of many high school and junior high school labs throughout the United Statesthese conditions are easy to forget, but they have a disastrous effect on students. We have to equip our future science teachers with the means to discuss the scientific method carefully and critically, with sound reasoning skills, and principles that science can live up to so that students can develop both a healthy respect for what science does and a critical understanding of how science achieves what it does.

Others have recommended devoting attention to critical reasoning and dialogue about science. In the book Denying Evolution, Massimo Pigliucci argues that the resurgence of creationism is related to a prevailing anti-intellectualism, and that the current versions of intelligent design are merely thinly disguised attempts to bring Christian content into schools. His recommendations for science educators include more open-inquiry exercises, teaching the "how" of 
science instead of the "what," and teaching communication skills. (Pigliucci 2002) Susan Froetschel recommends that we address the decline in American science students by "creating an environment that recognizes creativity-and values invention-requiring nurturing and respect...Closing the door to scientific talent out of fear and suspicion, discouraging scientists through neglect and low wages, is not how the US should alter the disturbing trends-falling numbers of students, scientists and patents" (Froetschel 2006)

One happy result of the Dover case is the wide array of narratives now available from those individuals who have successfully integrated their religious beliefs with the ideals of "good science." One member of the Dover community said that "As a Christian, he had been forced to think a lot about the issues raised by the trial... his faith was so deeply embedded in him, it was very hard to lose God from the equation. To him, the more significant question was "ready for prime time science," referring to the idea that intelligent design may simply not be ready to be called science yet-acknowledging that Darwin had spent over two decades collecting evidence before he presented his theory." (Chapman 2006, 61) Another example comes from the testimony of Keith Miller, a geologist from Wheaton College, Kansas State University, who is also a Christian. He upholds evolution and provides an example of how students can unify their interests in science with their spirituality.

The discussions Keith Miller had with students and faculty at Wheaton were covered in detail in a television series produced by WGBH Boston on Evolution. The seventh episode, "What About God?," illustrates how students can maintain an interest in science, even excel in science, while remaining true to their Christian faith. For example, a student named Nathan Baird shares his experience as a Geology major. On a field trip to a dig, he asks the faculty and the guides how they came to the conclusion that a particular layer of rock was millions of years old. He receives answers that are respectful and that bear the scrutiny of the scientific method.

On a trip home to see his parents, Nathan tells his father that he cannot simply dismiss science without trying to really understand it, and that he values the ongoing search for truth in which his religious and his scientific backgrounds both play roles. He assures his mother that he is not "losing his faith." Nathan's personal narrative is important not only because it shows how religion need not be a barrier to scientific enterprise, but because it shows how a constructive and critical dialogue can lead to better understanding on all sides.

My main objective is to inspire philosophers to educate students and future teachers in the sciences and in religious studies, and to encourage them to do so by using enriched narratives from fields like religion and ecology. If we can engage in this dialogue using critical reasoning skills, and with tolerance for religious beliefs, then we can make progress and not become bogged down in localized issues of disagreement like the evolution controversy. Teaching the scientific method in a sensitive and informed fashion will have obvious benefits for students and teachers of all religious perspectives. We will be prepared for 
controversies like Dover, and we can see individuals with differing views as potential conversation partners rather than adversaries. Students like those at Wheaton, and scientists who are pro-evolution as well as Christian, like Keith Miller, may prove to be the most effective voices and to provide the best narratives for educating the public and taking away the fear of science that negatively impacts our nation's science and technology education. Philosophers and sociologists of science can and should lead the way by enriching science education with critical discussions of science itself, and thus enabling science teachers and students to address issues like ID head on.

\section{Acknowledgements}

An early draft of this paper was presented at the inaugural meeting of the International Society for the Study of Religion, Nature and Culture on April 6-9, 2006. Thank you to those present for the session on Relating Science and Religion, whose comments and warm reception were incredibly important for the future of the paper. I was honoured to be in a session with Ed Rafferty and Claudia Pine. Thank you to the conference organizers whose work has inspired me, including Mary Evelyn Tucker and Mark Wallace, and thank you to my students at Valdosta State University who inspired this work.

\section{Special Thanks}

Lafayette, Indiana School Board

Buddy and Ken Ham

Students of Wheaton College

Nathan Baird, Geology Major, Wheaton College

Wheaton College

Derek Chignell, Professor, Wheaton College

Patti and Jim Baird, Nathan's parents

Emi Hayashi, Biochemistry Major, Wheaton College

Stanley Jones, Provost, Wheaton College

Keith Miller, Geology Professor, Kansas State University

Peter Slayton, Anthropology Major, Wheaton College

Beth Stuebing, Pre-Med, Wheaton College

Claire McKinney, Science Teacher, Lafayette, Indiana (Jefferson High School)

Eugenie Scott, National Center for Science Education

Steve Randak, science teacher, Lafayette, Indiana

Steve Fuller, Philosopher and Sociologist of Science, Warwick, UK 


\author{
CHRISTINE JAMES \\ Department of Philosophy and Religious \\ Studies \\ Valdosta State University \\ 1500 North Patterson St. \\ Valdosta, GA 31698-0050 \\ chjames@valdosta.edu
}

\title{
References
}

Alberts, B. 1997. Measuring What Counts In Science: A Speech by Bruce Alberts, President National Academy of Sciences Presented at the Academy's 134th Annual Meeting April 28, 1997.

Berube, M. 2006 Blog. http://www.michaelberube.com Accessed June 15, 2008.

Carpenter, D. 2006. Deconstructing Dover: An Expert Witness for the District Shares Lessons from 'Scopes 2005'. American School Board Journal, February 2006. 20-22.

Chapman, M. 2006. God or Gorilla: A Darwin Descendant at the Dover Monkey Trial. Harper's Magazine, February 2006. 54-63.

Christian Century Staff. 1999. Creation Mysteries. Christian Century, August 25September 1.

Cole, S. 2006. Witnessing Creation. Social Studies of Science 36(6):855-860.

Dowling-Sendor, B. 2006. Drawing the Line Between Science and Religion (2 part series). American School Board Journal, March 2006. 49-61.

Editor and Publisher Staff. 2006. Gallup: More Than Half of Americans Reject Evolution, Back Bible. Editor and Publisher, March 8, 2006.

Edmond, G. and D. Mercer. 2006. Anti-Social Epistemologies. Social Studies of Science 36(6):843-853.

Edmond, G. and D. Mercer. 1999. Creating Science: Science, Law and Religion in the Australian Noah's Ark Case. Public Understanding of Science 8: 317-343.

http://www.lessonlab.com/about/index.cfm/c/ab 80

A Teaching Style That Adds Up. Education Week. February 23, 2000.

http://www.edweek.org/ew/ewstory.cfm?slug=24timss.h19.

Fiske, E. Insights Into Why U.S. Students Lag Behind in Global Academic 'Horse Race, International Herald Tribune, Tuesday February 11, 1997. http://www.iht.com/articles/1997/02/11/math.t.phpc.

Froetschel, S. 2006. US Faces Serious Shortage of Qualified Scientists. The Nation, Yale Global Online, Nation Multimedia Wednesday April 5, 2006.

Fuller, S. 2006. A Step Toward the Legalization of Science Studies. Social Studies of Science 36(6): 827-834.

Fuller, S. 2006a. Reply to Berube, Michael. Blog. 
http://www.michaelberube.com.

Fuller, S. 2006b. A Witness in the Dover Trial Pits Motive Against Method. Science and Theology News, March 8, 2006.

Fuller, S. 2004. Kuhn Vs. Popper: The Struggle for the Soul of Science, New York: Columbia University Press.

Fuller, S. 2006c. Steve Fuller: Designer Trouble (interview). The Guardian, January 31, 2006.

George, M. 2001. And Then God Created Kansas? The Evolutionism/Creationism Debate in America's Public Schools. University of Pennsylvania Law Review. 3: 843-873.

Gieryn, T., G. Bevins and S. Zehr. 1985. Professionalization of American Scientists: Public Science in the Creation/Evolution Trials. American Sociological Review 50: 392-409.

Gorman, M. 2006. E. STS, Ethics, and Knowledge Transfer in the Courtroom. Social Studies of Science 36(6): 861-866.

Lambert, K. 2006. Fuller's Folly, Kuhnian Paradigms, and Intelligent Design. Social Studies of Science 36(6): 835-842.

Latour, B. 1987. Science in Action. Cambridge, MA: Harvard University Press.

Laudan, L. 1982. Science at the Bar-Causes for Concern. Science, Technology and Human Values 7:16-19.

Lowell, L. and H. Salzman. 2007. Into the Eye of the Storm: Education, Quality, and Workforce Demand.

http://www.urban.org/UploadedPDF/411562 Salzman Science.pdf.

Lynch, M. 2006. From Ruse to Farce. Social Studies of Science 36(6): 818-826.

Lynch, M. 2006a. Comments: Expert Metascientists. Social Studies of Science 36(6):867-868.

Martin, M. 2004. Class Warfare. Science and Spirit May/June 2004: 12-15.

Mercer, D. 2007. Capturing the Positive Educational Possibilities of Creation Science Debates? In Teaching About Scientific Origins: Taking Account of Creationism. Counterpoints: Studies in the Postmodern Theory of Education, eds. L. Jones and M. Reiss, pp 43-58. New York: Peter Lang.

Mirsky, S. 2006. Teach the Science. Scientific American 294(2): 36-38.

Moore, R. 2000. The Revival of Creationism in the United States. Journal of Biological Education 35(1): 17-21.

NSF InfoBrief. 2005. NSF 05-317. August 2005. http://www.nsf.gov/statistics/inbrief/nsf05317

Perkins, S. 2006. Evolution in Action. Science News 169(8):120-121.

Hice, C. 2002. Review of Pigliucci's Denying Evolution: Creationism, Scientism, and the Nature of Science. Journal of Mammalogy 85(6):1236-1237.

Read, D. 2005. Has Postmodernism Ruined Science and Software Development? A response to the October 2005 issue of Software Development. http://www.developerdotstar.com/community/node/261 
RNS. 2006. ID Ruling Expected to Impact Other States. Christian Century, January 24, 2006.

Ruse, M. 1982. Pro Judice (in Defense of Judge Overton). Science, Technology and Human Values 7:16-19.

Siegel, D., M. Acree, R. Bradley, S. Cole, D. Faigman, S. Fiehberg et al. 2006. The Reliability of Latent Print Individuation: Brief of Amici Curiae submitted on Behalf of Scientists and Scholars by The New England Innocence Project, Commonwealth v. Patterson. Criminal Law Bulletin 42(1): 21-51.

Simon, S. 2006. Their Own Version of a Big Bang. The Los Angeles Times, February 11, 2006.

Stoney, D. 2002. Fingerprint Identification: Scientific Status. In Modern Scientific Evidence: The Law and Science of Expert Testimony, eds. D. Faigman, D. Kaye, M. Saks and J. Sanders, 368-399. St. Paul, Minnesota: West Publishing Company.

Young, C. and M. Largent, eds. 2007. Evolution and Creationism: A Documentary and Reference Guide, New York: Greenwood Publishing Group.

Woodward, T. 2003. Doubts about Darwin: A History of Intelligent Design. Ada, MI: Baker Books. 